\title{
Pyrethroid insecticide neurotoxicity
}

\author{
C. van Thriel $\cdot$ J. G. Hengstler $\cdot$ R. Marchan
}

Published online: 14 February 2012

(C) Springer-Verlag 2012

Pyrethroid insecticides are one of the most widely used pesticides to combat agricultural pests and malaria. Compared with the group of the organophosphorus pesticides acting via the inhibition of acetylcholine esterase in either insects or mammals, the neurotoxic mechanism of pyrethroids is thought to be more species specific. Moreover, pyrethroids are the pesticide of choice in controlling bed bugs, parasitic insects feeding on human blood, which since 1995 are increasing in prevalence. The editors are pleased that David Soderlund from New York accepted our invitation to contribute a comprehensive review about the molecular mechanisms of pyrethroid neurotoxicity (Soderlund 2012). This is not only appreciated since neurotoxicity is one of the cutting-edge topics in toxicology (Frimat et al. 2010; Liu et al. 2010; Pamies et al. 2010; Romero et al. 2010; Sriram et al. 2010; Wagner et al. 2010; Ge et al. 2011; Hardelauf et al. 2011; Li et al. 2011; Nakamura et al. 2011; Takahasi et al. 2011; Wang et al. 2011; Yen et al. 2011) but also because recently the safety of pyrethroid insecticides has been discussed controversially. Traditionally pyrethroid insecticides are considered as relatively safe. They compromise the function of voltagegated sodium channels in insect neuronal membranes, which explains their insecticidal properties. In contrast, mammalian sodium channels were considered as much more resistant. Although this seems to apply in general, it has become clear that besides insensitive mammalian sodium cannels (e.g. $\mathrm{Na}_{\mathrm{v}}$ 1.2) also more sensitive isoforms exist (such as $\mathrm{Na}_{\mathrm{v}} 1.3, \mathrm{Na}_{\mathrm{v}} 1.6$ or $\mathrm{Na}_{\mathrm{v}}$ 1.8). Moreover,

C. van Thriel · J. G. Hengstler · R. Marchan $(\bowtie)$ Leibniz Institut für Arbeitsforschung an der TU Dortmund, Leibniz Research Centre for Working Environment and Human Factors (IfADo), Ardeystrasse 67, 44139 Dortmund, Germany e-mail: marchan@ifado.de pyrethroids may besides sodium channels also target voltage-gated calcium and chloride channels. Thus, another ongoing discussion is to which degree children are more susceptible than adults. The effects of pyrethroids on sodium channels are comparable to the mode of action of some anticonvulsants (e.g. phenytoin) that are associated with the foetal hydantoin syndrome (FHS) a neurodevelopment disorder occurring in epileptic women using these drugs during pregnancy (Bjorling-Poulsen et al. 2008). The review article of David Soderlund gives differentiated and comprehensive answers to these questions and is highly recommended to everybody interested in ion-channelmediated neurotoxicity.

\section{References}

Bjorling-Poulsen M, Andersen HR, Grandjean P (2008) Potential developmental neurotoxicity of pesticides used in Europe. Environ Health A Glob Access Sci Sourc 7:50

Frimat JP, Sisnaiske J, Subbiah S, Menne H, Godoy P, Lampen P, Leist M, Franzke J, Hengstler JG, van Thriel C, West J (2010) The network formation assay: a spatially standardized neurite outgrowth analytical display for neurotoxicity screening. Lab Chip 10:701-709

Ge Y, Niu R, Zhang J, Wang J (2011) Proteomic analysis of brain proteins of rats exposed to high fluoride and low iodine. Arch Toxicol 85:27-33

Hardelauf H, Sisnaiske J, Taghipour-Anvari AA, Jacob P, Drabiniok E, Marggraf U, Frimat JP, Hengstler JG, Neyer A, van Thriel C, West J (2011) High fidelity neuronal networks formed by plasma masking with a bilayer membrane: analysis of neurodegenerative and neuroprotective processes. Lab Chip 11:2763-2771

Li H, Wu S, Shi N, Lin W, You J, Zhou W (2011) NF-E2-related factor 2 activation in $\mathrm{PC} 12$ cells: its protective role in manganese-induced damage. Arch Toxicol 85:901-910

Liu X, Liu W, Jin Y, Yu W, Liu L, Yu H (2010) Effects of subchronic perfluorooctanesulfonate exposure of rats on calcium-dependent 
signaling molecules in the brain tissue. Arch Toxicol 84:471-479

Nakamura M, Yasutake A, Fujimura M, Hachiya N, Marumoto M (2011) Effect of methylmercury administration on choroid plexus function in rats. Arch Toxicol 85:911-918

Pamies D, Reig JA, Vilanova E, Sogorb MA (2010) Expression of neuropathy target esterase in mouse embryonic stem cells during differentiation. Arch Toxicol 84:481-491

Romero C, Benedí J, Villar A, Martín-Aragón S (2010) Involvement of Hsp70, a stress protein, in the resistance of long-term culture of PC12 cells against sodium nitroprusside (SNP)-induced cell death. Arch Toxicol 84:699-708

Soderlund D (2012) Molecular mechanisms of pyrethroid insecticide neurotoxicity: recent advances. Arch Toxicol 86:165-181

Sriram K, Lin GX, Jefferson AM, Roberts JR, Chapman RS, Chen BT, Soukup JM, Ghio AJ, Antonini JM (2010) Dopaminergic neurotoxicity following pulmonary exposure to manganesecontaining welding fumes. Arch Toxicol 84:521-540
Takahashi M, Inoue K, Koyama N, Yoshida M, Irie K, Morikawa T, Shibutani M, Honma M, Nishikawa A (2011) Life stage-related differences in susceptibility to acrylamide-induced neural and testicular toxicity. Arch Toxicol 85:1109-1120

Wagner C, Vargas AP, Roos DH, Morel AF, Farina M, Nogueira CW, Aschner M, Rocha JB (2010) Comparative study of quercetin and its two glycoside derivatives quercitrin and rutin against methylmercury ( $\mathrm{MeHg}$ )-induced ROS production in rat brain slices. Arch Toxicol 84:89-97

Wang Y, Zhao F, Jin Y, Zhong Y, Yu X, Li G, Lv X, Sun G (2011) Effects of exogenous glutathione on arsenic burden and NO metabolism in brain of mice exposed to arsenite through drinking water. Arch Toxicol 85:177-184

Yen CC, Ho TJ, Wu CC, Chang CF, Su CC, Chen YW, Jinn TR, Lu TH, Cheng PW, Su YC, Liu SH, Huang CF (2011) Inorganic arsenic causes cell apoptosis in mouse cerebrum through an oxidative stress-regulated signaling pathway. Arch Toxicol 85:565-575 